\title{
Indicators of Semen Quality of Roosters of Three Parental Layer Lines and Specific Conductivity of the Semen
}

\author{
L. MÁCHAL ${ }^{1}$, I. KŘIVÁNEK ${ }^{2}$ \\ ${ }^{1}$ Department of Farm Animal Reproduction, Faculty of Agronomy, \\ Mendel University of Agriculture and Forestry Brno, Czech Republic \\ 2 Department of Physics, Faculty of Agronomy, \\ Mendel University of Agriculture and Forestry Brno, Czech Republic \\ Received May 28, 2001 \\ Accepted October 31, 2001
}

\section{Abstract}

Máchal L., I. Křivánek: Indicators of Semen Quality of Roosters of Three Parental Layer Lines and Specific Conductivity of the Semen. Acta Vet. Brno 71, 2002: 109-116.

Relations between semen quality and the specific conductivity of the semen was determined in 90 clinically healthy roosters of three parental lines (BPR - 04, RIW - 06 and RIR - 05) in a breeding flock of the Moravia laying hybrids. At the age of 143, 205 and 240 days the volume, sperm concentration and sperm motility was measured in the ejaculates and at the age of 205 and 240 days also the specific conductivity. The average volume of the ejaculate of the cocks of all three parental lines ranged between $0.20 \mathrm{~cm}^{3}$ and $0.62 \mathrm{~cm}^{3}$. On the $143^{\text {rd }}$ day of age the average volume of the ejaculate was the lowest (between $0.20 \mathrm{~cm}^{3}$ and $0.30 \mathrm{~cm}^{3}$ ), and was the highest on the $240^{\text {th }}$ day (between $0.51 \mathrm{~cm}^{3}$ and $0.62 \mathrm{~cm}^{3}$ ). The average sperm motility of the ejaculate was similar; at the beginning of the investigations, i.e. on day 143 of age, it ranged between $31.7 \%$ and $54.1 \%$, at the age of 240 days it was higher $(66.8 \%-86.2 \%)$. The average sperm concentration was balanced, i.e. between $0.75 \cdot 10^{9} \mathrm{~cm}^{-3}$ and $1.06 \cdot 10^{9} \mathrm{~cm}^{-3}$. The average total number of sperm (TNS) in the ejaculate and the average total number of motile sperm in the ejaculate of the cocks (TNMS) increased with the age of the cocks. The average TNS increased from the initial $0.16 \cdot 10^{9}-0.32 \cdot 10^{9}$ on day143 of age to $0.38 \cdot 10^{9}-$ $0.59 \cdot 10^{9}$ on day 240 . The average TNMS also increased from the initial $0.09 \cdot 10^{9}-0.16$. $10^{9}$ on day 143 of age to $0.26 \cdot 10^{9}-0.51 \cdot 10^{9}$ on day 240 . In terms of inter-line difference the lowest average TNMS was reported in cocks of the RIR - 05 universal paternal line (between $0.09 \cdot 10^{9}$ and $0.26 \cdot 10^{9}$ ) and the highest in cocks of the BPR - 04 paternal line (between $0.09 \cdot 10^{9}$ and $0.51 \cdot 10^{9}$ ).

The average specific conductivity of the ejaculate was measured with four electrodes and ranged between $0.84 \mathrm{~S} \cdot \mathrm{m}^{-1}$ and $1.02 \mathrm{~S} \cdot \mathrm{m}^{-1}$. No marked differences in the average values of the specific conductivity were observed among cocks of the respective lines, but the lowest average specific conductivity was discovered in the ejaculates of cocks with the lowest number of motile sperms (line RIW -06 on the $205^{\text {th }}$ day of age, i.e. $1.02 \mathrm{~S} \cdot \mathrm{m}^{-1}$ ). Negative correlations were found between sperm concentration and motility and the specific conductivity of the ejaculate in cocks of all the three paternal lines of the domestic fowl $\left(r_{p}=-0.15\right.$ to -0.45$)$. The calculated correlations, particularly those that were statistically highly significant or significant (between sperm concentration, sperm motility and specific conductivity of the ejaculate) demonstrated that these properties could be used for complementary examinations of the ejaculate quality.

Roosters, sperm, ejaculate volume, sperm concentration, sperm motility, conductivity

The qualitative parameters of the ejaculates of roosters are considerably variable. In cocks of the paternal and maternal lines Št teň ová et al. (1989) reported differences in the volume of the ejaculate and sperm concentration; the average ejaculate volume in three generations of the paternal lines ranged between 0.34 and $0.55 \mathrm{~cm}^{-3}$, in the maternal lines between 0.37 and $0.57 \mathrm{~cm}^{-3}$. The average sperm concentration in the paternal line ranged between 3.78 and $4.78 \cdot 10^{6} \mathrm{~mm}^{-3}$, in the maternal line between 4.35 and $4.75 \cdot 10^{6} \mathrm{~mm}^{-3}$. Máchal et al.

Address for correspondence:

Doc. Ing. Ladislav Máchal, DrSc.

Department of Farm Animal Reproduction

Mendel University of Agriculture and Forestry Brno
Phone : +420545133259

Fax: +420 545133259

http://www.vfu.cz/acta-vet/actavet.htm 
(1996) reported similar findings. Suchý et al. (1997) reported that the average ejaculate volume of 24 - week old RIR cocks was $0.6 \mathrm{~cm}^{3}$, sperm motility $82.3 \%$ and sperm concentration $1.47 \cdot 10^{9} \mathrm{~cm}^{-3}$.

Permanent focus is on the electric and dielectric properties of the biological material, including the ejaculate. Kent (1987), Tran and Stuchly (1987) and Křivánek and Buchar (1993) measured the electric and dielectric properties of tissues of animals and their products.

Investigations of the quality and quantity of the cock ejaculate used for insemination purposes in breeding and reproduction flocks showed that the quality of the ejaculate of one and the same breeder was subject to changes; it is advisable to evaluate the ejaculates of the cocks used for these purposes. The respective tests are based on biological, chemical, biochemical and physical properties of the sperm.

Kozumplík and Kudláč (1980) reported that the values of the conductivity of the ejaculate (of boars) at $25^{\circ} \mathrm{C}$ in reciprocal ohms ranged between 123.3 and 134.6 $10^{-1} \mathrm{~S} \cdot \mathrm{m}^{-1}$. Máchal et al. (1997) studied the correlations among the relative permitivity, conductivity and qualitative characters of the boar and bull ejaculate. The calculated phenotypic correlations between the ejaculate volume and electric and dielectric properties of the fresh bull ejaculate were negative $\left(r_{p}=-0.17\right.$ to -0.72$)$. The average values of specific conductivity measured in the semen plasma with four and two electrodes were higher $(0.90$ and $0.75 \mathrm{~S} \cdot \mathrm{m}^{-1}$, respectively) than in the whole ejaculate $\left(0.84\right.$ and $0.69 \mathrm{~S} \cdot \mathrm{m}^{-1}$, respectively).

The discovered correlations between the qualitative parameters of the ejaculate and specific conductivity of the ejaculate suggest that they should be also checked in the domestic fowl.

\section{Materials and Methods}

The investigations were carried out in 90 clinically healthy roosters of three initial paternal lines of the breeding flock of the Moravia SSL and Moravia BSL laying hybrids. The ejaculate was collected from cocks at the age of 143,205 and 240 days. In the first sampling, at 143 days of age, 18 cocks were taken out because we did not manage to collect their ejaculate. The cocks were placed in cages of one each in the laying hall; their sisters were subjected to performance testing. Until performance testing (phase I) was finished and cocks for the next generation were selected, only condition sampling was performed once a month. Cocks of three laying lines were selected for the investigations - Bar Plymouth Rock (BPR - 04), Rhode Island White (RIW - 06) and Rhode Island Red (RIR 05 ). The earliness of the respective lines differs and is usually expressed in reaching $50 \%$ of the egg yield. According to this parameter the earliest line was RIW - 06 ( 20 weeks of age), the middle was RIR - 05 ( 22 weeks) and the late line was BPR - 04 (24 weeks).

Immediately after collection the sperm motility of the ejaculate was determined in the laboratory at a temperature of $39.0 \pm 1.0^{\circ} \mathrm{C}$, then the volume and sperm concentration. The haemocytometric method was used to determine the sperm concentration of each ejaculate (counting in Bürker's chamber).

The electric conductivity of the ejaculate was measured (four-electrode method) 5 minutes after collection of the ejaculate in the same laboratory at approximately $35^{\circ} \mathrm{C}$. Prior to the measurement proper the ejaculate was stirred.

The specific conductivity $\sigma$ was assessed using the bio-impedance spectroscopic analyser Z01 of the firm OMNI $\mathrm{BIO}$, which allows measuring conductivity as a function of the frequency. The measurements ranged between 10 $\mathrm{Hz}$ and $100 \mathrm{kHz}$ and so it was possible to determine any potential phase shift in the electric signal inside the sample and the capacity component of conductivity.

The carriers of conduction currents, which arise in the electrolytes (and these are all biological materials), are free ions, which can move among the other particles in conductive substances. These particles are either neutral, and the external electric field does not affect them, or they are bound to the only slightly variable position in the crystal lattice. The particles obstruct the movement of the carriers of the charge and they resist the electric current. Ohm's law in the differential form holds for the spatial density of the electric current, also in dependence on the electrostatic field of intensity E:

$$
\mathrm{i}=\sigma \mathrm{E}
$$

where the constant of proportionality is called specific conductivity, which is defined as: 


$$
\sigma=\frac{n \cdot e \cdot \bar{t}}{2 m}
$$

$\mathrm{n}$ - spatial density of the charges

$\mathrm{e}$ - charge of the mobile particle

$\mathrm{t}$ - mean time of flight of the particle between two collisions

$\mathrm{m}$ - mass of the charges

The conductivity of the dimension of the conductive sample is:

$$
G=\sigma \cdot \frac{S}{l}
$$

$\mathrm{G}$ - conductivity of sample $(\mathrm{S})$

$\sigma-$ specific conductivity $\left(\mathrm{S} \cdot \mathrm{m}^{-1}\right)$

1 - length of sample

$\mathrm{S}-$ area of sample $\left(\mathrm{m}^{2}\right)$

During measuring it is necessary to define the specific conductivity $\sigma$, which is a constant of the sample for the given frequency, but not conductivity $\mathrm{G}$ the size of which is based on the area and length of the sample. In literature we see that the specific conductivity is often substituted by the term conductivity, only using the $\mathrm{S} \cdot \mathrm{m}^{-1} \mathrm{unit}$. Ohm's law applies for the correlation between the voltage on sample $\mathrm{U}$, conductive current I inside, and conductivity G:

$$
G=\cdot \frac{I}{U}
$$

This correlation shows that if constant voltage can be maintained on the contacts of the measuring probe, the conductivity is in direct proportion to the size of the current flowing between the contacts. The majority of available conductivity meters use direct-current voltage and current, what is inadequate for measuring liquids and biological material, because in the course of the measurements electrolysis appears on the probe contacts and the contact electric resistance increases.

Due to the volume of the ejaculate samples of the cocks and in order to eliminate errors due to contact impedance resistance we used a special four-contact probe, inside diameter $1 \mathrm{~mm}$, which requires a minimal $0.1 \mathrm{~cm}^{3}$ of ejaculate for the measuring. The following relation holds for the conductance probe:

$$
\sigma=\mathrm{K} \cdot \mathrm{G}
$$

where $\mathrm{K}\left(\mathrm{m}^{-1}\right)$ is the conductivity constant defined using normal liquid - a $20 \%$ solution of $\mathrm{NaCl}$ of a 19.61 $\mathrm{S} \cdot \mathrm{m}^{-1}$ specific conductivity.

The principle of the four-contact measurement consists in the fact that two electrodes of the probe are supply electrodes, to which the electric signal of the given frequency is brought, and two electrodes are sensing electrodes. The sensing electrodes which measure the voltage inside the sample, are connected to an alternating electronic voltmeter with an input resistance in the order of hundreds M. In this way the effect of the transient resistance of the sample - sensing contacts - is eliminated.

The frequency dependence of conductivity was assessed in the ejaculate samples using the internal electronics of the Z01 apparatus, which is capable of automatic returning of the frequency with step $10 \mathrm{~s}$.

The obtained qualitative and quantitative data of sperm parameters and their dielectric and electric properties were interpreted using routine statistical methods $\left(x, s_{x}, \min , \max \right)$. The closeness of the correlations between the parameters of the ejaculate quality and their specific conductivity measured with four electrodes were interpreted using the calculated phenotypic correlations. At the same time within the studied initial lines we explored the closeness of the correlation between the quantity and the qualitative parameters of the ejaculate of the individual cocks at various age.

\section{Results}

The average volume of the collected ejaculates of the roosters differed not only between cocks of the respective paternal lines, but particularly between the various ages (Table 1). At the age of 143 days it ranged between $0.20 \mathrm{~cm}^{3}$ and $0.30 \mathrm{~cm}^{3}$, while at 240 days it was considerably higher and ranged between $0.51 \mathrm{~cm}^{3}$ and $0.62 \mathrm{~cm}^{3}$. The average motility of sperm in the cock ejaculate showed a similar trend; at the beginning of our investigations at the age of 143 days it ranged between $31.7 \%$ and $54.1 \%$ and at 240 days of age it was higher, 
Table 1

The average values of the sperm quality indicators and conductivity of the ejaculte in roosters of the initial lines

\begin{tabular}{|l|c|c|c|c|c|c|c|c|}
\hline Line & Age & $\mathrm{n}$ & $\begin{array}{c}\text { Volume } \\
\text { of ejaculate } \\
\left(\mathrm{cm}^{3}\right)\end{array}$ & $\begin{array}{c}\text { Sperm } \\
\text { Motility } \\
(\%)\end{array}$ & $\begin{array}{c}\text { Concentration } \\
\text { of sperms } \\
\left(\cdot 10^{9} \cdot \mathrm{cm}^{-3}\right)\end{array}$ & $\begin{array}{c}\text { Conductivity } \\
\left(\mathrm{S} \cdot \mathrm{m}^{-1}\right)\end{array}$ & $\left(\cdot 10^{9}\right)$ & TNS \\
\hline BPR -04 & 143 & 23 & $0.20 \pm 0.14$ & $54.1 \pm 30.2$ & $0.84 \pm 0.61$ & & $0.16 \pm 0.10$ & $0.09 \pm 0.07$ \\
& 205 & 23 & $0.27 \pm 0.23$ & $85.3 \pm 16.8$ & $1.01 \pm 0.61$ & $0.86 \pm 0.12$ & $0.27 \pm 0.16$ & $0.23 \pm 0.18$ \\
& 240 & 23 & $0.56 \pm 0.22$ & $86.2 \pm 21.8$ & $1.05 \pm 0.42$ & $0.88 \pm 0.16$ & $0.59 \pm 0.24$ & $0.51 \pm 0.27$ \\
\hline RIR -05 & 143 & 25 & $0.27 \pm 0.06$ & $31.7 \pm 15.0$ & $1.03 \pm 0.55$ & & $0.27 \pm 0.19$ & $0.09 \pm 0.04$ \\
& 205 & 25 & $0.28 \pm 0.11$ & $86.9 \pm 11.3$ & $0.88 \pm 0.47$ & $0.92 \pm 0.09$ & $0.25 \pm 0.17$ & $0.22 \pm 0.14$ \\
& 240 & 25 & $0.51 \pm 0.20$ & $66.8 \pm 30.8$ & $0.75 \pm 0.46$ & $0.86 \pm 0.21$ & $0.38 \pm 0.24$ & $0.26 \pm 0.21$ \\
\hline RIW-06 & 143 & 24 & $0.30 \pm 0.18$ & $49.7 \pm 28.0$ & $1.06 \pm 0.65$ & & $0.32 \pm 0.27$ & $0.16 \pm 0.13$ \\
& 205 & 24 & $0.30 \pm 0.14$ & $69.3 \pm 23.3$ & $0.91 \pm 0.46$ & $1.02 \pm 0.09$ & $0.27 \pm 0.19$ & $0.19 \pm 0.12$ \\
& 240 & 24 & $0.62 \pm 0.26$ & $68.2 \pm 30.2$ & $0.96 \pm 0.49$ & $0.84 \pm 0.11$ & $0.59 \pm 0.23$ & $0.41 \pm 0.18$ \\
\hline
\end{tabular}

i.e. $66.8 \%-86.2 \%$. The average sperm concentration was balanced and ranged between $0.75 \cdot 10^{9} \mathrm{~cm}^{-3}$ and $1.06 \cdot 10^{9} \mathrm{~cm}^{-3}$. The average sperm number in the cock ejaculate at 143 days of age ranged between $0.16 \cdot 10^{9}$ and $0.32 \cdot 10^{9}$, at the age of 240 days ranged between $0.38 \cdot 10^{9}$ and $0.59 \cdot 10^{9}$. The average total number of motile sperms in the ejaculate at 140 days of age in cocks of all the three lines was low and ranged between $0.09 \cdot 10^{9}$ and 0.16 . $10^{9}$ sperms. The average conductivity at 205 days of age was higher (i.e. $0.86 \mathrm{~S} \cdot \mathrm{m}^{-1}-1.02$ $\mathrm{S} \cdot \mathrm{m}^{-1}$ ) than at 240 days of age (i.e. $0.84 \mathrm{~S} \cdot \mathrm{m}^{-1}-0.88 \mathrm{~S} \mathrm{~m}^{-1}$ ).

Table 2

Phenotypic correlations between the respective indicators of the ejaculate quality in roosters of lines BPR - 04, RIR - 05 and RIW - 06 at the age of 143, 205 and 240 days

\begin{tabular}{|c|c|c|c|c|c|}
\hline \multirow{2}{*}{$\begin{array}{l}\text { Line } \\
\text { (age) }\end{array}$} & \multicolumn{5}{|c|}{ Indicators of the ejaculate quality } \\
\hline & $\begin{array}{l}\text { Ejaculate } \\
\text { volume }\end{array}$ & $\begin{array}{l}\text { Sperm } \\
\text { motility }\end{array}$ & $\begin{array}{c}\text { Sperm } \\
\text { concentration }\end{array}$ & TNS & TNMS \\
\hline $\begin{array}{l}\text { BPR - } 04 \\
143 \text { days: } \\
205 \text { days } \\
143 \text { days: } \\
240 \text { days } \\
205 \text { days : } \\
240 \text { days }\end{array}$ & $\begin{array}{c}++ \\
0.68 \\
0.18 \\
-0.01\end{array}$ & $\begin{array}{c}0.08 \\
0.02 \\
++ \\
0.67\end{array}$ & $\begin{array}{l}-0.11 \\
-0.34 \\
0.11\end{array}$ & $\begin{array}{l}0.35 \\
0.07 \\
0.28\end{array}$ & $\begin{array}{l}0.22 \\
0.13 \\
0.36\end{array}$ \\
\hline $\begin{array}{l}\text { RIR - } 05 \\
143 \text { days: } \\
205 \text { days } \\
143 \text { days: } \\
240 \text { days } \\
205 \text { days : } \\
240 \text { days }\end{array}$ & $\begin{array}{l}0.15 \\
0.36 \\
0.33\end{array}$ & $\begin{array}{c}0.20 \\
+ \\
-0.45 \\
+ \\
0.46\end{array}$ & $\begin{array}{c}++ \\
-0.59 \\
+ \\
0.52 \\
\\
0.22\end{array}$ & $\begin{array}{c}-0.15 \\
++ \\
0.64 \\
0.23\end{array}$ & $\begin{array}{l}0.04 \\
0.14 \\
0.19\end{array}$ \\
\hline $\begin{array}{l}\text { RIW - } 06 \\
143 \text { days: } \\
205 \text { days } \\
143 \text { days: } \\
240 \text { days } \\
205 \text { days: } \\
240 \text { days }\end{array}$ & $\begin{array}{c}+ \\
0.47 \\
++ \\
0.58 \\
++ \\
0.56\end{array}$ & $\begin{array}{l}-0.02 \\
0.05 \\
0.42\end{array}$ & $\begin{array}{c}0.22 \\
+ \\
0.52 \\
\\
0.13\end{array}$ & $\begin{array}{c}0.12 \\
++ \\
0.72 \\
0.33\end{array}$ & $\begin{array}{c}-0.07 \\
++ \\
0.67 \\
\\
0.30\end{array}$ \\
\hline
\end{tabular}

++ Significant $(P<0.01)$

+ Significant $(P<0.05)$ 
The phenotypic correlations for the respective parameters of the semen quality in cocks of all the three paternal lines at various ages shows Table 2. As concerns the ejaculate volume, a highly significant closeness of the correlation $(P<0.01)$ was discovered in the BPR - 04 cocks between the age of 143 and 205 days $\left(r_{p}=0.68\right)$ and in the RIW - 06 cocks between the age of 143 and 240 days $\left(r_{p}=0.58\right)$ and between 205 and 240 days of age $\left(r_{p}=\right.$ 0.56). Between the age of 143 and 205 days (line RIW - 06) the closeness of the correlation $\left(\mathrm{r}_{\mathrm{p}}=0.47\right)$ was found to be significant $(P<0.05)$. The closeness of the correlation in the sperm motility of BPR -04 cocks between the age of 205 and 240 days $\left(\mathrm{r}_{\mathrm{p}}=0.67\right)$ was highly significant $(P<0.01)$, and significant $(P<0.05)$ in RIR -05 cocks between the age of 143 and 240 days $\left(r_{p}=0.45\right)$ and between the age of 205 and 240 days $\left(r_{p}=0.46\right)$. A highly significantly close correlation $(P<0.01)$ of the sperm concentration was estimated only in cocks of the RIR - 05 lines between the age of 143 and 205 days $\left(r_{p}=-0.59\right)$, and this correlation was significant in the RIR $-05\left(r_{p}=0.52\right)$ and RIW $-06 \operatorname{cocks}\left(r_{p}=0.52\right)$ between the age of 143 and 240 days. A highly significantly close correlation of the total sperm number $(P<0.01)$ was estimated in the RIR - 05 and RIW - 06 cocks between the age of 143 and 240 days $\left(r_{p}=0.64\right.$ and $r_{p}=0.72$, respectively); of the total number of motile sperms TNMS only in the RIW - 06 cocks between the age of 143 and 240 days $\left(r_{p}=0.67\right)$.

Table 3 shows the relation between the specific conductivity of the ejaculate and the individual parameters of the ejaculate in cocks of all the three lines at the age of 205 and 240 days. A highly significant close relation was found between the conductivity and ejaculate

Table 3

Phenotypic correlations between the respective indicators of the ejaculate qualityand the specific conductivity in roosters of the lines BPR - 04, RIR - 05 and RIW - 06 at the age of 205 and 240 days

\begin{tabular}{|l|c|c|c|}
\hline & \multicolumn{2}{|c|}{ Conductivity } & Total \\
\cline { 2 - 4 } & 205 days of age & 240 days of age & 0.06 \\
BPR - 04 & 0.17 & -0.38 & + \\
Semen volume & -0.28 & -0.32 & + \\
Sperm motility & 0.02 & ++ & -0.35 \\
Sperm concentration & & -0.61 & 0.08 \\
\hline RIR - 05 & -0.25 & 0.28 & +- \\
Semen volume & ++ & -0.15 & ++ \\
Sperm motility & -0.73 & -0.39 \\
Sperm concentration & + & -0.21 & + \\
\hline RIW - 06 & -0.47 & & +0.40 \\
Semen volume & & +0.51 & -0.22 \\
Sperm motility & -0.27 & -0.32 & -0.15 \\
Sperm concentration & 0.06 & 0.22 & + \\
\hline
\end{tabular}

++ Significant $(P<0.01)$

+ Significant $(P<0.05)$

volume, i.e. in the RIW - 06 cocks at the age of 240 days $\left(r_{p}=-0.51\right)$ and also for both observations $\left(r_{p}=-0.40\right)$. A highly significant correlation closeness was found between the conductivity and sperm motility $(P<0.01)$ in the RIR -05 cocks at the age of 205 days $\left(r_{p}=-0.73\right)$ and also for both observations $\left(r_{p}=-0.45\right)$. The correlation closeness between sperm concentration and conductivity was also highly significant $(P<0.01)$ in the BPR -04 
cocks at the age of 240 days $\left(r_{p}=-0.61\right)$ and RIR -05 cocks during the entire period of observations and for both observations $\left(\mathrm{r}_{\mathrm{p}}=-0.39\right)$, and was significant $(P<0.05)$ in the BPR -04 cocks in the both periods of observations $\left(r_{p}=-0.35\right)$.

\section{Discussion}

The average ejaculate volume in the cocks of all three paternal lines ranged between 0.20 $\mathrm{cm}^{3}$ and $0.62 \mathrm{~cm}^{3}$. It was in agreement with data of Šteňová et al. (1989), Máchal et al. (1996) and Suchý et al. (1997). The lowest average ejaculate volume was observed at the age of 143 days $\left(0.20 \mathrm{~cm}^{3}-0.30 \mathrm{~cm}^{3}\right)$ and the highest at the age of 240 days $\left(0.51 \mathrm{~cm}^{3}-0.62\right.$ $\left.\mathrm{cm}^{3}\right)$. The increasing average values of the ejaculate volume based on the age of the cocks are accordant with the development of the cocks' gonads (Suchý et al., 1998). The average sperm motility in the ejaculate of the cocks showed a similar tendency; at the beginning, at 143 days of age, it ranged between $31.7 \%$ and $54.1 \%$ and was higher at 240 days of age $(66.8 \%-86.2 \%)$. The average sperm concentration was balanced and ranged between 0.75 . $10^{9} \mathrm{~cm}^{-3}$ and $1.06 \cdot 10^{9} \mathrm{~cm}^{-3}$. The average sperm concentration and sperm motility at the age of 205 and 240 days was in accordance with the data of Suchý et al. (1997).

The average total number of sperm in the semen (TNS) and the average total number of motile sperm in the ejaculate of the cocks (TNMS), both important in terms of the number of insemination doses from one ejaculate, definitely increased in dependence on the age of the cocks. The average TNS increased from the initial values of $0.16 \cdot 10^{9}-0.32 \cdot 10^{9}$ at 143 days of age to $0.38 \cdot 10^{9}-0.59 \cdot 10^{9}$ at the age of 240 days. Similarly, the average TNMS ranged between $0.09 \cdot 10^{9}$ and $0.16 \cdot 10^{9}$ at 143 days of age and increased to $0.26 \cdot 10^{9}-0.51$ $\cdot 10^{9}$ at 240 days of age. Interesting differences between the lines were observed; the lowest average TNMS was reported in cocks of the universal paternal line (which participates in the formation of the laying hybrid Moravia SSL and Moravia BSL) RIR - 05, i.e. from 0.09 $\cdot 10^{9}$ to $0.26 \cdot 10^{9}$, and the highest in cocks of the paternal line BPR - 04, i.e. from $0.09 \cdot 10^{9}$ to $\left.0.51 \cdot 10^{9}\right)$.

The correlation coefficients between the different ages of the cocks (143, 205 and 240 days of age) for the respective indicators of the quality of the ejaculate, particularly the low, zero or negative values, indicate that individual selection of cocks to be used for insemination cannot be based only on the first collections of ejaculates and on the assessment of qualitative parameters, because they change considerably in the course of the entire reproductive period. Altogether 27 correlations were calculated for ejaculate volume, sperm motility and sperm concentration and only 5 were on the level of close dependence $(P<0.05)$ and 5 on the level of very close dependence $(P<0.01)$.

The average values of specific conductivity of the ejaculate of cocks measured using four electrodes, ranged between $0.84 \mathrm{~S} \cdot \mathrm{m}^{-1}$ and $1.02 \mathrm{~S} \cdot \mathrm{m}^{-1}$ and were higher than values discovered in the bull ejaculate (Máchal et al. 2000). No marked differences in the average values of specific conductivity were found among cocks of the respective lines; however, the highest average specific conductivity $\left(1.02 \mathrm{~S} \cdot \mathrm{m}^{-1}\right)$ was discovered in the ejaculate of cocks, which had the lowest total number of motile sperms (line RIW - 06, 205 days of age). In terms of the found correlations it is evident that particularly the relation between the concentration and motility of the sperms on the one hand, and the specific conductivity on the other hand, are markedly negative. The values of phenotypic correlations in both observations ranged between $\left(r_{p}=-0.15\right.$ and -0.45$)$. The correlations in the ejaculate of cocks of line BPR $-04\left(r_{p}=-0.31\right.$ and -0.35$)$ were on the level of close dependence $(P<0.05)$ and in the ejaculate of cocks of the line RIR $-05\left(r_{p}=-0.39\right.$ and -0.45$)$ on the level of very close dependence $(P<0.01)$.

It can be concluded that between the individual indicators of the quality of the ejaculate and specific conductivity of the ejaculate in cocks of three initial parental lines of the 
domestic fowl the dependence was mostly negative, while between the sperm concentration and motility and the specific conductivity it was always negative and ranged between $r_{p}=-$ 0.15 and -0.45 . The correlation relationships, especially where the dependence was statistically highly significant or significant (between sperm concentrations in the cock ejaculate), sperm motility and specific conductivity of the ejaculate disclosed that these properties could be used for complementary examinations of the quality of the ejaculate.

\section{Vztahy mezi ukazateli kvality ejakulátu plemenných kohoutů tří otcovských snáškových linií a měrnou vodivostí ejakulátu}

Sledování probíhalo u 90 klinicky zdravých plemenných kohoutů tří výchozích otcovských linií (BPR - 04, RIW - 06 a RIR - 05) ve šlechtitelském chovu snáškových hybridů Moravia. Ve věku 143, 205 a 240 dnů byl u získaných ejakulátů stanoven jeho objem, koncentrace spermií a motilita spermií, ve věku 205 a 240 dnů také měrná vodivost ejakulátu.

Průměrný objem ejakulátu u sledovaných kohoutů všech tří otcovských linií se pohyboval $\mathrm{v}$ rozpětí $0,20 \mathrm{~cm}^{3}$ až $0,62 \mathrm{~cm}^{3}$. Ve 143 dnech věku byl zjištěný průměrný objem ejakulátu nejnižší $\left(0,20 \mathrm{~cm}^{3}\right.$ až $\left.0,30 \mathrm{~cm}^{3}\right)$, ve 240 dnech věku nejvyšší $\left(0,51 \mathrm{~cm}^{3}\right.$ až $\left.0,62 \mathrm{~cm}^{3}\right)$. Podobnou tendenci vykázala i průměrná motilita spermií v ejakulátu kohoutů. Na počátku sledování ve 143 dnech věku se pohybovala v rozpětí $31,7 \%$ až $54,1 \%$, ve 240 dnech věku byla vyšší $(66,8 \%$ až $86,2 \%)$. Průměrná koncentrace spermií byla vyrovnaná a pohybovala se v rozmezí $0,75 \cdot 10^{9} \cdot \mathrm{cm}^{-3}$ až $1,06 \cdot 10^{9} \cdot \mathrm{cm}^{-3}$. Průměrný celkový počet spermií $\mathrm{v}$ ejakulátu (TNS) a průměrný celkový počet aktivních spermií v ejakulátu kohoutů (TNMS) vykazoval nárůst $\mathrm{v}$ závislosti na věku kohoutů. Průměrný TNS se zvyšoval z počátečních $0,16 \cdot 10^{9}$ až $0,32 \cdot 10^{9}$ ve 143 dnech věku na $0,38 \cdot 10^{9}$ až $0,59 \cdot 10^{9}$ ve 240 dnech věku. Podobně i průměrný TNMS z $0,09 \cdot 10^{9}$ až $0,16 \cdot 10^{9}$ ve 143 dnech věku na $0,26 \cdot 10^{9}$ až 0,51 - $10^{9}$ ve 240 dnech věku. Z hlediska meziliniové diference vykázali nejnižší průměrný TNMS kohouti univerzální otcovské linie RIR - $05\left(0,09 \cdot 10^{9}\right.$ až $\left.0,26 \cdot 10^{9}\right)$, nejvyšší průměrný TNMS vykázali kohouti otcovské linie BPR - $04\left(0,09 \cdot 10^{9}\right.$ až $\left.0,51 \cdot 10^{9}\right)$.

Zjištěné průměrné hodnoty měrné vodivosti ejakulátu kohoutů, měřené čtyř elektrodově, se pohybovaly v rozpětí $0,84 \mathrm{~S} . \mathrm{m}^{-1}$ až $1,02 \mathrm{~S}^{-1} \mathrm{~m}^{-1}$. Mezi kohouty jednotlivých linií nebyly zjištěny výrazné diference $\mathrm{v}$ průměrných hodnotách měrné vodivosti, avšak u ejakulátů kohoutů s nejnižším celkovým počtem aktivních spermií (linie RIW - 06, 205 dnů věku)

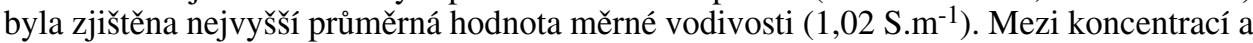
motilitou spermií a měrnou vodivostí ejakulátu u kohoutů tří výchozích otcovských linií kura domácího byly zjištěny vždy negativní korelace $\mathrm{v}$ rozpětí $\left(\mathrm{r}_{\mathrm{p}}=-0,15\right.$ až $\left.-0,45\right)$. Vypočtené korelační vztahy, zvlášt se statisticky vysoce významnou nebo významnou závislostí (mezi koncentrací spermií v ejakulátu kohoutů, motilitou spermií a měrnou vodivostí ejakulátu), svědčí o možnosti využití těchto vlastností k doplňujícímu vyšetř̌ení kvality ejakulátu.

\section{Acknowledgements}

This work was supported by MSM 432100001.

\section{References}

KENT, M. 1987: Electrical and dielectric properties of food materials. Hornbuch, Science and Technology Publishers, Essex, $252 \mathrm{p}$.

KOZUMPLÍK, J., KUDLÁČ, E. 1980: Reprodukce prasat ve velkochovech. SZN Praha, 290 p.

KŘIVÁNEK, I., BUCHAR, J. 1993: Dielektrické vlastnosti sýrů. Acta Univ. Agric. et Silvic. Mendel. Brun. 26: 171-185

MÁCHAL, L., KALOVÁ, J., JURÁŇ, P., JEŘÁBEK, S. 1996: The dynamics of the relationship between ejaculate quality and cholesterol and total lipids concentration in the blood plasma in two lines of the cocks. Arch. Tierzucht. 39: 61-68 
MÁCHAL, L., KŘIVÁNEK, I., CHLÁDEK, G., DOLEŽAL, P.1997: Correlation between the relative permitivity and electric conductivity, and qualitative indicators of bull and boar ejaculates. J. Anim. Feed Sci. 6:13-22

MÁCHAL, L., KŘIVÁNEK, I. 2000: The dielectrical indicators of the bull ejaculate and semen plasma. Acta Univ.

Agric. et Silvic. Mendel. Brun. 48: 7-13

SUCHY, P., STRAKOVÁ, E., ILLEK, J. 1997: Relationships between haematological and reproductive indices in breeder cocks. Živoč. Výr. 42: 361-366

SUCHY, P., STRAKOVÁ, E., ILLEK, J., ŠIMON, M.1998: Effect of applications of various forms of zinc on gonad development in breeding cocks. Czech J. Anim. Sci. 43: 343-348

ŠTEŇVÁ, M., LEDEČ, M., CSUKA, J., ŠKROBÁNEK, P. 1989: Zhodnotenie produkcie a kvality ejakulátu kohútov v dvoch líniách hybridnej kombinácie Slovgal. Živoč. Výr. 34: 91-96

TRAN, V. N., STUCHLY, S. S. 1987: Dielectric properties of beef liver, chicken and salmon at frequencies from 100 to 2500 Mhz. J. Microwave Power EE 22: 29-33 